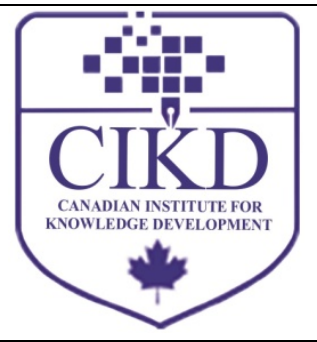

\title{
Turkish Validation of the Work-Family Conflict Scale
}

\author{
İlksun Didem Ülbeği
}

Cukurova University, Faculty of Economics and Administrative Sciences, Department of Business Administration, 2nd Block, 3rd Floor, Office: 321, 01380, Balcalı / Sarıçam / ADANA / TURKEY

\begin{abstract}
Keywords:

work-family conflict, scale validation, validity, reliability, Turkish sample

\section{Received}

08 May 2018

Received in revised form 05 August 2018

Accepted

24 August 2018

The aim of this study is to translate and validate work-family conflict scale abbreviated and developed by Matthews, Kath and Barnes-Farrell (2010) in a Turkish sample. The present study was conducted in a sample of 317 bank employees. The confirmatory factor analysis revealed two-factor structure work-to-family and family-to-work conflict dimensions of the original scale. The convergent, discriminant, and nomological validity analyses showed satisfactory results. Reliability analyses indicated that the scale had high internal consistency and sufficient item correlations. The findings revealed that the Turkish version of work-family conflict scale is a valid and reliable instrument to examine work-family conflict in Turkish context.

Correspondence:

idulbegi@cu.edu.tr

(C)AIMI Journals

\section{Turkish Validation of the Work-Family Conflict Scale}

Work and family roles occupy both important places in employees' lives. These two individual roles in life are not isolated from each other. On the contrary, they are associated in various ways (Ilies, Liu, Liu, \& Zheng, 2017). This relationship has widely examined by "role scarcity" and "negative spillover" perspectives in many studies (Tetrick \& Buffardi, 2006). As a consequence of these approaches, the most widely studied aspect of work-family interface has been work-family conflict (Greenhaus \& Powell, 2003).
\end{abstract}


Work-family conflict can be defined as "a form of inter role conflict in which the role pressures from the work and family domains are mutually incompatible in some respect" (Greenhaus \& Beutell, 1985, p. 77). This conflict can occur from both directions whereas work life can have an effect on family life and family life can have an effect on work life (Tetrick \& Buffardi, 2006). Both of these domain interferences have significant effects on work related, family related, health related outcomes, including job satisfaction, career satisfaction, organizational commitment, absenteeism, turnover intentions, job performance, life satisfaction, family satisfaction, burnout, psychological strain, work-related stress, and familyrelated stress (Anderson, Coffey, \& Byerly, 2002; Aycan \& Eskin, 2005; Bruck, Allen, \& Spector, 2002; Burke \& Greenglass, 2001a; Grandey, Cordeiro, \& Crouter, 2005; Lapierre, Spector, Allen, Poelmas, Coopere, O’Driscoll, Sanchez, Brough, \& Kinnunen, 2008; Michel, Mitchelson, Kotrba, LeBreton, \& Baltes, 2009; Nohe \& Sonntag, 2014).

There are several measures in order to assess work-family conflict in the literature. Bellavia and Frone (2005), MacDermid (2005), and Tetrick and Buffardi (2006) summarized workfamily conflict measures in a detail. Tetrick and Buffardi (2006) stated that early measures of work-family conflict are bidirectional, which assess work life interfering with family life (e.g. Bohen \& Viveros-Long, 1981). Carlson, Kacmar, and Williams (2000) noted that following measures have taken into consideration the directionality of work-family conflict meaning work life interfering with family life and as well as family life interfering with work life (e.g. Frone, Russell, \& Cooper, 1992; Gutek, Searle, \& Klepa, 1991; Kopelman, Greenhaus, \& Connoly, 1983, Netemeyer, Boles, \& McMurrian, 1996). Recent studies have recognized various sources of conflict and have created distinct dimensions for time-based conflict, strainbased conflict, and behavior-based conflict (e.g. Carlson et al., 2000; Stephens \& Sommer, 1996). Even though Stephens and Sommer (1996) utilized time-based, strain-based, and behavior-based conflict dimensions, they only measured work-family conflict, which refers to work life interfering with family life. On the other hand, Carlson et al. (2000) developed a multidimensional measure containing the three types and two directions of work-family conflict which leads to time-based work-to-family conflict, strain-based work-to-family conflict, behavior-based work-to-family conflict, time-based family-to-work conflict, strainbased family-to-work conflict, and behavior-based family-to-work conflict subscales.

However, as Matthews, Kath, and Barnes-Farrell (2010) stated, elongated measures can be an issue in some studies such as longitudinal research designs whereas a concise instrument containing theoretical relevant items proves to be more advantageous. The aim of the present study is to translate and validate this measure by Turkish sample and utilize it in the Turkish context. Thereby it is expected to contribute to the literature by enabling this instrument on the work-family and family-work conflict, which can have important consequences for both the employees work life and family life as well as for the organization.

\section{Background}

The interaction between work life and family life has received much interest over past several decades especially due to the changes in socioeconomic and family structures such as rising number of women in the workforce, increasing working hours, the grate share of dual-earner families, the growing rate of working single parents, and responsibility of child care and aging 
parents (Annor, 2013; Kinnunen, Rantanen, Mauno, \& Peeters, 2014; Mokomane, 2013; Parasuraman \& Greenhaus, 1997). Moreover, globalization of economy and technological developments changed work life and working conditions by giving means of working out of the office remotely and after office hours (Kinnunen et al., 2014) which eventually leads in the interaction between work roles and family roles. This interaction can be either positive or negative (Allen, 2013; Carlson \& Grzywacz, 2008; Kinnunen et al., 2014). Negative workfamily interaction in other words work-family conflict has been the most widely studied subject in the work-family literature (Poelmans, O’Driscoll, \& Beham, 2005).

The majority of the literature based theoretical foundation of the work-family conflict on Kahn, Wolfe, Quinn, Snoek, and Rosenthal's (1964) role stress theory and the scarcity approach (Allen, 2013; Grzywacz \& Butler, 2008; Kinnunen et al., 2014; MacDermid, 2005). According to role theory, taking part in one role becomes incompatible with taking part in the other role resulting inter role conflict (Greenhaus \& Beutell, 1985). Scarcity approach suggests that people have limited resources such as time, energy, and emotions and these individual reserves can easily drain while participating these various roles (Goode, 1960; Marks, 1977). As both roles can interfere with one another, work roles interact with family roles (work-tofamily conflict), and family roles interact with work roles (family-to-work conflict) conflict can occur from both domains indicating that work-family conflict is a bidirectional concept (Allen, 2013; Frone, 2003; MacDermid, 2005).

Greenhaus and Beutell (1985) suggested that the type of conflict between work and family roles could have three major bases, time-based conflict, strain-based conflict, and behaviorbased conflict involving both domains. Time-based conflict emerges when time required for one role obstructs participating in the other role. Strain-based conflict occurs when the strain caused by one role prevents fulfilling the demands of the other role. Behavior-based conflict arises when behaviors appropriate for one role are not suitable for the expected behaviors of the other role (Allen, 2013; Geurts \& Demerouti, 2003; Greenhaus \& Beutell, 1985; Kinnunen et al., 2014; MacDermid, 2005; Matthews et al., 2010; Parasuraman \& Greenhaus, 1997).

Work-to-family conflict and family-to-work conflict have significant effects on the organizations as well as on the employees and their families. As Kinnunen et al (2014) pointed out early studies suggested that work-to-family conflict has effects on the family area whereas family-to-work conflict has consequences for the work area implying that each domain has outcomes for the cross domain. However, in their meta-analysis Allen, Herst, Bruck, and Sutton (2000) revealed that work-to-family conflict has a correlation with not only non-workrelated outcomes but also work-related and health-related outcomes in contrast to the crossdomain rule. This implies that both domains could have effects on work-related, non-workrelated, and health-related consequences.

Work-family conflict has negative effects on individuals' health and well-being (Bellavia \& Frone, 2005; Geurts \& Demerouti, 2003). O'Driscoll, Brouh, and Kalliath (2004) revealed in their study that both work-family conflict domains are associated with physical health symptoms and psychological strain. Van Steenbergen and Ellemers (2009) found that work-tofamily conflict has negative effects on physical health while family-to-work conflict has no significant effect. Several other studies reported similar results regarding physical health 
outcomes and psychological strain (Gareis, Barnett, Ertel, \& Berkman, 2009; Grzywacz, 2000; Kalliath, Kalliath, \& Chan, 2014).

Frone's (2000) research results indicated that work-to-family and family-to-work conflict linked to having a mood, anxiety, and substance abuse disorders. Frone, Russell and Cooper (1997) revealed that conflict between work and family roles in both domains lead to depression and heavy alcohol use. In their meta-analysis, Amstad, Meier, Fasel, Elfering, and Semmer (2011) reported that work interference with family and family interference with work are both related to anxiety, depression, stress, and substance abuse. Similarly, Wang and Peng (2017) reported positive relationships between work-to-family conflict, family-to-work conflict and depression.

In their study, Burke and Greenglass (2001b) found that family-to-work conflict has positive associations with burnout. Similarly, Bacharach, Bamberger, and Conley (1991) reported positive relationships between work-to-family conflict and burnout in two different samples. Rupert, Stevanovic, and Hunley (2009) found that both work-family conflict domains are related to burnout subscales, personal accomplishment, emotional exhaustion, and depersonalization.

Regarding the effects of the work-family conflict on satisfaction such as job satisfaction, life satisfaction, and family satisfaction, Netemeyer et al. (1996) showed in their study that workto-family conflict and family-to-work conflict are in association with job satisfaction, life satisfaction, and family satisfaction negatively in three different samples. Moreover, O'Driscoll et al. (2004) revealed that both domains are negatively related with job satisfaction and family satisfaction. In their meta-analysis, Kossek and Ozeki (1998) found that work-to-family conflict and family-to-work conflict have negative correlations with job satisfaction and life satisfaction. Shockley and Singla (2011) showed in the meta-analysis that work interfering with family and family interfering with work are correlated negatively with job satisfaction and family satisfaction. In their more recent meta-analysis, Amstad et al. (2011) reported that work-family-conflict in both domains are inversely related to life satisfaction, marital satisfaction, and family satisfaction.

Furthermore, Aryee, Srinivas, and Tan (2005) demonstrated that work-family conflict in both domains are related to organizational commitment in a negative way. In addition to this, Netemeyer et al. (1996) found similar results that work-family-conflict is associated with organizational commitment in opposite directions. Moreover, Amstad et al. (2011) revealed in their meta-analysis that higher levels of work interference with family and family interference with work is correlated at lower levels of organizational commitment.

With respect to the effect of work-to-family conflict and family-to-work conflict on job performance and family performance, Frone, Yardley, and Markel (1997) found that workfamily-conflict in both domains are negatively related to job performance and family performance. In addition to this, in their meta-analysis, Hobler, Hu, and Wilson (2010) reported that higher levels of work-family-conflict is associated with lower levels of self-rated and manager-rated job performance.

Moreover, in regard to the negative influence of work-family-conflict on withdrawal behavior, absenteeism, and turnover intentions, in their meta-analysis, Mesmer-Magnus and Viswesvaran (2005) reported that work-to-family conflict and family-to-work both are 
correlated to withdrawal from work. Anderson et al. (2002) and Boyar, Maertz, and Pearson (2005) revealed that higher levels of work-family conflict in both directions are associated with high levels of absenteeism. Furthermore, several studies showed that work-family conflict in both domains are related with high levels of turnover intentions (Anderson et al., 2002; Boyar, Maertz, Pearson, \& Keough, 2003; Greenhaus, Parasuraman, \& Collins, 2001; Netemeyer, Brashear-Alejandro, \& Boles, 2004).

\section{Method}

\section{Translation Process}

In order to translate the work-family conflict scale, the method developed by Bristlin, Lonner, and Thorndike (1973) was utilized. Initially, the scale was translated into Turkish from the original language by two language experts who had experience in English speaking countries. Secondly, two professors from the field of organizational behavior assessed the scale. In the next step, the experts back translated the Turkish version into original language and this version was examined in detail. The two professors checked the final version of the work-family conflict scale at the last step of the translation process.

\section{Sample}

The sample in this study comprised of bank employees in Adana, Turkey. In total, 350 questionnaires were distributed, 330 of them were returned. Due to several reasons, (e.g. missing information) 13 questionnaires were eliminated, and thus the sample consisted of 317 employees in total. The sample included $48.9 \%$ (155) female. The participants mean age was 37.96 years $(S D=6.73)$ and the mean job tenure was 7.01 years $(S D=5.35)$. Most of the participants had a bachelor's degree $(81.1 \%)$ regarding their education level.

\section{Instruments}

\section{Work-Family Conflict}

Work-Family conflict was measured with using two-dimensional scale abbreviated and developed by Matthews, Kath and Barnes-Farrell (2010) using the long version of the scale of work-family conflict by Carlson, Kacmar, and Williams (2000). This scale consists of six items which assesses two factors, work-to-family and family-to-work conflict. 5-point Likert scale was used ( 1 = strongly disagree, $5=$ strongly agree) to assess the scale. Matthews et al. (2010) reported alpha coefficients for work-to-family conflict dimension ranging from .75 to .80 whereas for family-to-work conflict dimension ranging from .71 to .72. In the present study, Cronbach's alpha and McDonald's omega reliability coefficients for work-to-family conflict factor were .80 and .81 whereas these coefficients for family-to-work conflict factor were .77 and .78 .

\section{Life Satisfaction}

Life satisfaction was assessed using a 5-item Life Satisfaction scale created by Diener, Emmons and Griffin (1985). The original scale rated on a 7-point Likert scale, but this study used a 5-point scale ( $1=$ strongly disagree, $5=$ strongly agree). Diener et al. (1985) and 
reported Cronbach's alpha value of .87. In this study, both Cronbach's alpha and McDonald's omega coefficients were found to be .89 .

\section{Subjective Happiness}

Subjective happiness scale (Lyubomirsky \& Lepper, 1999) was used regarding well-being. This scale consists of 4-items, which uses 7-point Likert scale. In this study, 5-point frequency scale was employed. Lyubomirsky and Lepper (1999) obtained a Cronbach's alpha value of .87. In the present study, Cronbach's alpha and McDonald's omega were found to be .87 and .88 .

\section{Depression}

Depression was examined using the depression dimension of work-related depression, anxiety, and irritation scale, which was developed by Caplan, Cobb, French, Van Harrison, and Pinneau (1980). This measure has 6 -items and uses a 5-point Likert scale $(1=$ never, $5=$ always $)$ in the present study. The reliability coefficient of this scale ranged from .81 to .88 in several studies (Begley \& Czajka, 1993; Jalajas, 1994; Kaufmann \& Beehr, 1986). In this study, alpha was found to be .92 and omega was .93 .

\section{Statistical Analyses}

The two-factor model developed by Matthews et al. (2010) was tested. Data analyses were performed with R Studio version 0.99.903 based on R Version 3.3.1 (R Core Team, 2016). In addition to R core packages psych (Revelle, 2017), Qgraph (Epskamp, Cramer, Waldorp, Schmittmann, \& Borsboom, 2012), and SemPlot (Epskamp with Stuber, 2017) were also utilized for data analyses purposes. Confirmatory factor analysis was conducted using Lavaan package (Rosseel, 2012) with maximum likelihood estimation method. Model fit was assessed by several goodness-of-fit statistics, the chi-square $\left(\chi^{2}\right)$ statistic, the comparative fit index (CFI; Bentler, 1990), the Tucker-Lewis fit index (TLI; Tucker \& Lewis, 1973), the root mean square error of approximation (RMSEA; Steiger \& Lind, 1980), and the standardized root mean square residual (SRMR; Bentler, 1995). For assessing the construct validity, convergent validity, discriminant validity, and nomological validity were examined (Hair, Black, Babin, \& Anderson, 2014, pp. 631). According to Hair et al. (2014, pp. 605) to establish convergent validity, the standardized factor loadings should be .50 or higher and optimally .70 . In addition to this, the average variance extracted (AVE) values should be greater than .50 whereas composite reliability coefficients (CR) should be .70 or higher for the convergent validity and for internal consistency (Hair et al., 2014, pp. 605). To assess discriminant validity, maximum shared variance (MSV) and average shared variance (ASV) should be lower than average variance extracted (AVE) and moreover the squared root of AVE's should be higher than the correlations between the variables (Hair et al., 2014, pp. 631). To examine nomological validity, the assumed relationships between constructs are evaluated with correlation analysis. For assessing the internal consistency of the scales, Cronbach's alpha (Cronbach, 1951) and McDonald's omega (McDonald, 1999) coefficients (Composite reliability coefficient) were used. Moreover, item and item-total statistics were analyzed to examine the reliability of the scales. According to Nunnally and Bernstein (1994, pp. 305), the corrected item-total correlations should be .30 or higher. 


\section{Results}

\section{Reliability Results}

For assessing the reliability, both item analysis and internal consistency were examined. As shown in Table 1, item-total correlations were obtained between .59 and .72. This result meets the requirement of item-total correlations as being higher than 30 (Nunnally \& Bernstein, 1994, pp. 305). In addition to this, item analysis revealed that deleting any items from the scale would not increase Cronbach's alpha values.

Table 1

Reliability Analysis of the Work-Family Conflict Scale

\begin{tabular}{|c|c|c|c|c|}
\hline Items & $\begin{array}{c}\text { Corrected Item-Total } \\
\text { Correlation }\end{array}$ & Alpha If Item Deleted & $M$ & $S D$ \\
\hline \multicolumn{5}{|c|}{ Work-to-Family Conflict Items } \\
\hline WF1 & .72 & .65 & 1.57 & .74 \\
\hline WF2 & .59 & .79 & 1.59 & .75 \\
\hline WF3 & .63 & .74 & 1.50 & .74 \\
\hline \multicolumn{5}{|c|}{ Family-to-Work Conflict Items } \\
\hline FW1 & .62 & .68 & 1.62 & .75 \\
\hline FW2 & .62 & .68 & 1.63 & .76 \\
\hline FW3 & .59 & .72 & 1.33 & .60 \\
\hline
\end{tabular}

Internal consistency of the scales was analyzed using both Cronbach's alpha and McDonald's omega coefficients. According to the results (Table 4) alpha coefficient for workfamily conflict dimension is .80 and omega coefficient is .81 whereas alpha coefficient for family-work conflict dimension is .77 and omega coefficient is .78. These internal consistency values which are above .70 show acceptable results.

\section{Confirmatory Factor Analysis (CFA)}

The confirmatory factor analysis results show very good model fit (Table 2). According to model fit indices, chi-square is 9.54 with 8 degrees of freedom and p-value is .298, which is statistically not significant. Moreover, CFI and TLI have a value of .99 whereas SRMR is .02 and RMSEA has a value of .02 .

Table 2

Confirmatory Factor Analysis Model Fit Results

\begin{tabular}{lll}
\hline Fit Index & Model Results & Reference Values $^{*}$ \\
\hline$\chi^{2}$ & 9.54 & $0 \leq \chi^{2} \leq 2 \mathrm{df}$ \\
$\mathrm{df}$ & 8 & - \\
$\chi^{2} / \mathrm{df}$ & 1.19 & $0 \leq \chi^{2} / \mathrm{df} \leq 2$ \\
$\mathrm{p}$-value & .29 & $\mathrm{P}>.00$ \\
CFI & .99 & $.90<\mathrm{CFI}$ \\
TLI & .99 & $.90<\mathrm{TLI}$ \\
RMSEA & .02 & $.00<$ RMSEA $<.05$ \\
SRMR & .02 & $.00<$ SRMR $<.05$ \\
\hline$\chi^{2}=$ Chi-Square, df=Degrees of Freedom, CFI=Comparative Fit Index, TLI=Tucker-Lewis Index, RMSEA=Root Mean Square Error of \\
Approximation, SRMR=Standardized Root Mean Square Residual, "Reference Values adapted from Bayram, 2010; Hair et al., 2014; Meydan \\
\& SSeşen, 2011.
\end{tabular}

According to confirmatory factor analysis, the standardized factor loadings are given in Table 3. These factor loadings range from .67 to .87 showing the model is well defined. The 
correlation between these factors, work-family conflict and family-work conflict is .46 as seen in Figure 1.

Table 3

Factor Loadings of the Work-Family Conflict Scale

\begin{tabular}{lcc}
\hline Items & Work-to-Family Conflict & Family-to-Work Conflict \\
\hline Work-to-Family Conflict Items & & \\
WF1 & .87 & \\
WF2 & .67 & \\
WF3 & .74 & .76 \\
Family-to-Work Conflict Items & & .74 \\
FW1 & & .69 \\
FW2 & & \\
FW3 & & \\
\hline
\end{tabular}

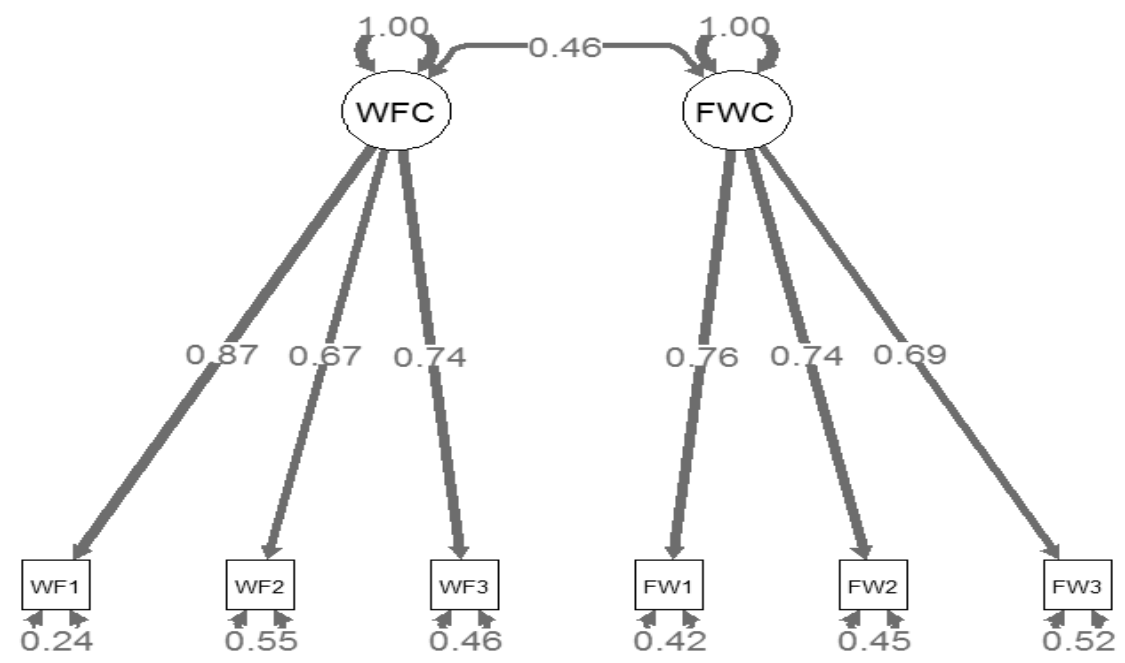

Figure 1 . Work-family conflict scale confirmatory factor analysis results

\section{Validity Results}

After establishing factorial validity with confirmatory factor analysis, for further evaluation of construct validity, convergent validity, discriminant validity, and nomological validity have been examined. For assessing convergent validity of work-family conflict scale, several criteria were utilized. Firstly, factor loadings should be higher than .50 or preferably .70 (Hair et al., 2014, pp. 605). According to the analysis results as shown in Table 3, the minimum factor loading is .67 which ensures convergent validity. Secondly the average variance extracted values should be higher than .50 for establishing the convergent validity (Hair et al., 2014, pp. 605). According to the results (Table 4), average variance extracted value for work-to-family conflict is .59 and for family-to-work conflict is .54 which are both above .50 . In addition, the last criterion for convergent validity is providing composite reliability coefficients higher than .70 (Hair et al., 2014, pp. 605) and according to the results (Table 4), composite reliability coefficient for work-to-family conflict is .81 and for family-to-work conflict is .78. These three rules suggest that convergent validity is established for the work-family conflict scale. 
Table 4

Means, Standard Deviations, Cronbach's Alphas, McDonald's Omegas, Composite Reliabilities, AVEs, and Correlations of the Scales Used

\begin{tabular}{|c|c|c|c|c|c|c|c|c|c|c|c|c|}
\hline Variables & $\alpha$ & CR- $\omega$ & AVE & MSV & ASV & Mean & SD & WFC & FWC & LS & $\mathrm{SH}$ & $\mathrm{D}$ \\
\hline WFC & .80 & & .59 & .22 & .19 & 1.55 & .63 & .77 & & & & \\
\hline FWC & .77 & .81 & .54 & & .30 & 1.53 & .58 & $.47 * *$ & .73 & & & \\
\hline LS & .89 & $\begin{array}{l}.78 \\
.89\end{array}$ & .61 & $\begin{array}{l}.33 \\
.35\end{array}$ & .30 & 4.45 & .60 & $-43^{* *}$ & $-58 * *$ & .78 & & \\
\hline $\mathrm{SH}$ & .87 & $\begin{array}{l}.88 \\
.93\end{array}$ & .64 & $\begin{array}{l}.38 \\
.38\end{array}$ & .31 & 4.04 & .72 & $-42 * *$ & - & $.58 * *$ & .80 & \\
\hline $\mathrm{D}$ & .92 & & .68 & & .31 & 1.95 & .75 & $.43^{* *}$ & $.55^{* *}$ & $.59 * *$ & $.62 * *$ & .82 \\
\hline
\end{tabular}

In order to examine the discriminant validity of the scale, the principles concerning AVE values were taken into consideration. According to these principles, AVE values should be higher than MSV and ASV values, whereas the square root of AVE values should be higher than the correlations between the variables (Hair et al., 2014, pp. 631). As displayed in Table 4, the AVE value for work-to-family conflict is .59 and for family-to-work conflict is .54 while MSV values and ASV values are lower than these results. In addition to this, in Table 4, the diagonal values show the square root of AVEs that are higher than the correlations between the variables. These findings reveal that discriminant validity is established for the work-family conflict scale.

To assess the nomological validity, the relationships between the variables were examined. As shown in Table 4, the correlations of work-to-family conflict and family-to-work conflict with life satisfaction and subjective happiness are positive whereas with depression are negative as expected according to the theoretical framework. These findings suggest that workfamily conflict scale has satisfactory reliability and construct validity comprising convergent, discriminant, and nomological validities.

\section{Discussion}

The aim of this study was to examine the validity and reliability of the work-family conflict scale developed by Matthews et al. (2010) in a Turkish sample. The results of this research show satisfactory support for both validity and reliability of the work-family conflict scale in Turkish sample. Confirmatory factor analysis results produce two-factor structure work-tofamily conflict and family-to-work conflict as in the original scale. Factor loadings were above .50 mostly above .70 and were all statistically significant. These findings show consistency with the earlier studies conducted in various cultures and contexts (Annor \& AmponsahTawiah, 2017; Hill, Morganson, Matthews, \& Atkinson, 2016; Rudolph, Michel, Harari \& Stout, 2014). 
In addition to this, the study established construct validity of the two-factor scale by showing convergent validity, discriminant validity, and nomological validity. This result is consistent with previous studies (Annor \& Amponsah-Tawiah, 2017; Matthews et al., 2010).

With regard to reliability of the scale, the results showed sufficient internal consistency and reliability. Cronbach's alpha and McDonald's omega coefficients for both subscales were obtained above .70 . Cronbach's alpha values for work-to-family conflict was .80 whereas for family-to-work conflict was .77 . McDonald's omega coefficient for work-to-family conflict was .81 and for family-to-work conflict was .78. In addition to these values, item-total correlations, which are another indicator of reliability, showed satisfactory results between .59 and .72 . These reliability values are consistent with the result conducted previously (Annor \& Amponsah-Tawiah, 2017; Hill et al. 2016; Matthews et al., 2010; Rudolph et al., 2014).

As Matthews et al. (2010) suggested that the abbreviated version of the work-family conflict scale is especially useful for studies requiring fewer items in the survey and longitudinal studies. This short version of work-family conflict measure is convenient in order to examine the overall aspect of work-family conflict rather than assessing the different basis such as timebased, strain-based, or behavior-based work-family and family-work conflict dimensions and theoretical distinctions. Therefore, the long version developed by Carlson et al. (2000) is more relevant as pointed out by Matthews et al. (2010).

This study has several limitations. The research was conducted only in one sample due to the financial and time constraints. Regarding the participants, only bank employees were recruited which can have an effect on the behaviors encountered. Moreover, the nomological validity was assessed with only three variables. In the future, the studies may conduct in multiple samples, with participants from several occupations, and examine various outcome and predictor variables in relation with work-family conflict.

In future studies, this valid and concise scale can be used to examine the relationships between work-family conflict and several outcomes important for family life, work life, and personal well-being of employees. In addition to this, regarding the concise nature of the scale, future research may conveniently use in longitudinal designs in order to assess work-family conflict, its outcomes, and predictors.

The present study indicates that the work-family conflict scale has two-factor structure, and these dimensions show sufficient reliabilities. In addition to these properties, this study shows that the construct validity involving convergent validity, discriminant validity, and nomological validity were established for the Turkish sample. These results indicate that work-family conflict scale shows satisfactory psychometric characteristics and this scale is a valid and reliable construct to use in studies for Turkish samples.

\section{References}

Allen, T. D. (2013). The work-family role interface: A synthesis of the research from industrial and organizational psychology. In N. W. Schmitt \& S. Highhouse (Eds.), Handbook of psychology volume 12: Industrial and organizational psychology second edition (pp. 698-718). Hoboken, NJ: John Wiley \& Sons, Inc.

Allen, T. D., Herst, D. E., Bruck, C. S., \& Sutton, M. (2000). Consequences associated with work-to-family conflict: A review and agenda for future research. Journal of Occupational Health Psychology, 5(2), 278-308.

Amstad, F. T., Meier, L. L., Fasel, U., Elfering, A., \& Semmer, N. K. (2011). A meta-analysis of work-family conflict and various outcomes with a special emphasis on cross-domain versus matching-domain relations. Journal of Occupational Health Psychology, 16(2), 151-169. 
Anderson, S. E., Coffey, B. S., \& Byerly, R. T. (2002). Formal organizational initiatives and informal workplace practices: Links to work-family conflict and job-related outcomes. Journal of Management, 28(6), 787-810.

Annor, F., \& Amponsah-Tawiah, K. (2017). Evaluation of the psychometric properties of two scales of work-family conflict among Ghanaian employees. The Social Science Journal 54,336-345.

Annor, F. (2013). Chapter 2. Managing work and family demands: The perspectives of employed parents in Ghana. In Z. Mokomane (Ed.), Work-Family interface in Sub-Saharan Africa: Challenges and responses, (pp. 17-36). New York, NY: Springer.

Aryee, S., Srinivas, E. S., \& Tan, H. H. (2005). Rhythms of life: Antecedents and outcomes of work-family balance in employed parents. Journal of Applied Psychology, 90(1), 132-146.

Aycan, Z., \& Eskin, M. (2005). Relative contributions of childcare, spousal support, and organizational support in reducing work-family conflict for men and women: The case of Turkey. Sex Roles, 53(7/8), 453-471.

Bacharach, S.B., Bamberger, P., \& Conley, S. (1991). Work-home conflict among nurses and engineers: Mediating the impact of role stress on burnout and satisfaction at work. Journal of Organizational Behavior, 12(1), 39-53.

Bayram, N. (2010). Yapısal eşitlik modellemesine giriş [Introduction to structural equation modeling]. İstanbul: Ezgi Kitabevi.

Begley, T. M., \& Czajka, J. M. (1993). Panel analysis of the moderating effects of commitment on job satisfaction, intent to quit, and health following organizational change. Journal of Applied Psychology, 78, 552-556.

Bellavia. G., \& Frone, M. (2005). Work-family conflict. In J. Barling, E. K. Kelloway, \& M. Frone (Eds.), Handbook of work stress, (pp. 113-147). Sage Publications: Thousand Oaks.

Bentler, P. M. (1990). Comparative fit indexes in structural models. Psychological Bulletin, 107, 238-246.

Bentler, P. M. (1995). EQS structural equations program manual. Encino, CA: Multivariate Software.

Bohen, H., \& Viveros-Long, A. (1981). Balancing jobs and family life. Philadelphia: Temple University Press.

Boyar, S. L., Maertz, C. P., Jr., \& Pearson, A. W. (2005). The effects of work-family conflict and family-work conflict on nonattendance behaviors. Journal of Business Research, 58(7), 919-925.

Boyar, S. L., Maertz, C. P., Jr., Pearson, A. W., \& Keough, S. (2003). Work-family conflict: A model of linkages between work and family domain variables and turnover intentions. Journal of Managerial Issues, 15(2), 175-190.

Bristlin, R. W., Lonner, W. J., \& Thorndike, R. M. (1973). Cross-cultural research methods. New York: John Wiley \& Sons.

Bruck, C. S., Allen, T. D., \& Spector, P. E. (2002). The relation between work-family conflict and job satisfaction: A finergrained analysis. Journal of Vocational Behavior, 60, 336-353.

Burke, R. J., \& Greenglass, E. R. (2001a). Hospital restructuring stressors, work-family concerns and psychological well-being among nursing staff. Community, Work, and Family, 4(1), 49-62.

Burke, R. J., \& Greenglass, E. R. (2001b). Hospital restructuring, work-family conflict and psychological burnout among nursing staff. Psychology and Health, 16(5), 583-594.

Caplan, R. D., Cobb, S., French, J. R. P., Jr., Harrison, R. V., \& Pinneau, S. R., Jr. (1980). Job demands and worker health: Main effects and occupational differences. Ann Arbor: Institute for Social Research. (Originally published as HEW Publication No. (NIOSH) 75-106, 1975.)

Carlson, D. S., \& Grzywacz, J. G. (2008). Reflections and future directions on measurement in work-family research. In K. Korabik \& D. L. Whitehead (Eds.), Handbook of work-family integration: Research, theory, and best practices (pp. 57-73). San Diego, CA: Academic Press.

Carlson, D. S., Kacmar, K. M., \& Williams, L. J. (2000). Construction and initial validation of a multidimensional measure of work-family conflict. Journal of Vocational Behavior, 56(2), 249-276.

Cronbach, L. J. (1951). Coefficient alpha and the internal structure of tests. Psychometrika, 16, 297-334.

Diener, E., Emmons, R. A., Larsen, R. J., \& Griffin, S. (1985). The satisfaction with life scale. Journal of Personality Assessment, 49, 71-75.

Epskamp, S. \& with contributions from Stuber, S. (2017). SemPlot: Path Diagrams and Visual Analysis of Various SEM Packages' Output. R package version 1.1. https://CRAN.R-project.org/package=semPlot.

Epskamp, S., Cramer, A. O. J., Waldorp, L. J., Schmittmann, V. D., \& Borsboom, D. (2012). Qgraph: Network visualizations of relationships in psychometric data. Journal of Statistical Software, 48(4), 1-18. URL http://www.jstatsoft.org/v48/i04/.

Frone, M. R. (2000). Work-Family conflict and employee psychiatric disorders: The national comorbidity survey. Journal of Applied Psychology, 85(6), 888-895.

Frone, M. R. (2003). Work-family balance. In J. C. Quick \& L. E. Tetrick (Eds.), Handbook of occupational health psychology (pp. 143-162). Washington, DC: American Psychological Association. 
Frone, M. R., Russell, M., \& Cooper, M. L. (1992). Prevalence of work-family conflict: Are work and family boundaries asymmetrically permeable? Journal of Organizational Behavior, 13, 723-729.

Frone, M. R., Russell, M., \& Cooper, M. L. (1997). Relation of work-family conflict to health outcomes: A four-year longitudinal study of employed parents. Journal of Occupational and Organizational Psychology, 70(4), 325-335.

Frone, M. R., Yardley, J. K., \& Markel, K. S. (1997). Developing and testing an integrative model of the work-family interface. Journal of Vocational Behavior, 50, 145-167.

Gareis, K. C., Barnett, R. C., Ertel, K. A., \& Berkman, L F. (2009). Work-family enrichment and conflict: Additive effects, buffering, or balance? Journal of Marriage and Family, 71, 696-707.

Geurts, S. A. E., \& Demerouti, E. (2003). Work/Non-Work interface: A review of theories and findings. In M. J. Schabracq, J. A. M. Winnubst, \& C. L. Cooper. (Eds.), The Handbook of work and health psychology $2^{\text {nd }}$ edition (pp. 279-312). Chichester, West Sussex: John Wiley \& Sons, Ltd.

Goode, W. J. (1960). A theory of role strain. American Sociological Review, 25(4), 483-496.

Grandey, A. A., Cordeiro, B. L., \& Crouter, A. C. (2005). A longitudinal and multi-source test of the work-family conflict and job satisfaction relationship. Journal of Occupational and Organizational Psychology, 78, 305-323.

Greenhaus, J. H., \& Beutell, N. J. (1985). Sources of conflict between work and family roles. Academy of Management Review, 10(1), 76-88.

Greenhaus, J. H., \& Powell, G. N. (2003). When work and family collide: Deciding between competing role demands. Organizational Behavior and Human Decision Processes, 90, 291-303.

Greenhaus, J. H., Parasuraman, S., \& Collins, K. M. (2001). Career involvement and family involvement as moderators of relationships between work-family conflict and withdrawal from a profession. Journal of Occupational Health Psychology, 6, 91-100

Grzywacz, J. G. \& Butler, A. B. (2008). Work-family conflict. In J. Barling \& C. L. Cooper (Eds.), The sage handbook of organizational behavior (Vol.1, pp. 451-468). Los Angeles, CA: Sage Publications.

Grzywacz, J. G. (2000). Work-Family spillover and health during midlife: Is managing conflict everything? American Journal of Health Promotion, 14(4), 236-243.

Gutek, B. A., Searle, S., \& Klepa, L. (1991). Rational versus gender role explanations for work-family conflict. Journal of Applied Psychology, 76(4), 560-568.

Hair, J. F., Black, W. C., Babin, B J., \& Anderson, R. E. (2014). Multivariate data analysis. Pearson International Edition, $7^{\text {th }}$ Edition. US: Pearson Education Limited.

Hill, R. T., Morganson, V. J., Matthews, R. A., \& Atkinson, T. P. (2016). LMX, breach perceptions, work-family conflict, and well-being: A mediational model. The Journal of Psychology, 150(1), 132-149.

Hobler, J. M., Hu, J., \& Wilson, M. (2010). Do workers who experience conflict between the work and family domains hit a "glass ceiling?": A meta-analytic examination. Journal of Vocational Behavior, 77(3), 481-494.

Ilies, R., Liu, X. Y., Liu, Y., \& Zheng, X. (2017). Why do employees have better family lives when they are highly engaged at work? Journal of Applied Psychology, 102(6), 956-970.

Jalajas, D. S. (1994). The role of self-esteem in the stress process: Empirical results from job hunting. Journal of Applied Social Psychology, 24(22), 1984-2001.

Kahn, R. L., Wolfe, D. M., Quinn, R. P., Snoek, J. D., \& Rosenthal, R. A. (1964). Organizational stress: Studies in role conflict and ambiguity. New York: John Wiley \& Sons.

Kalliath, P., Kalliath, T., \& Chan, C. (2014). Work-family conflict and family-work conflict as predictors of psychological strain: Does social support matter? The British Journal of Social Work, 45(8), 2387-2405.

Kaufmann, G. M., \& Beehr, T. A. (1986). Interactions between job stressors and social support: some counterintuitive results. Journal of Applied Psychology, 71(3), 522-526.

Kinnunen, U., Rantanen, J., Mauno, S., \& Peeters, M. C. W. (2014). Work-Family interaction. In M. C. W. Peeters, J. de Jonge, \& T. W. Taris (Eds.), An introduction to contemporary work psychology, (pp. 267-289). Chichester, West Sussex: John Wiley \& Sons, Ltd.

Kopelman, R. E., Greenhaus, J. H., \& Connolly, T. F. (1983). A model of work, family, and interrole conflict: A construct validation study. Organizational Behavior and Human Performance, 32, 198-215.

Kossek, E. E., \& Ozeki, C. (1998). Work-family conflict, policies, and the job-life satisfaction relationship: A review and directions for organizational behavior-human resources research. Journal of Applied Psychology, 83, 139-149. 
Lapierre, L. M., Spector, P. E., Allen, T. D., Poelmans, S., Cooper, C. L., O’Driscoll, M. P., Sanchez, J. I., Brough, P., \& Kinnunen, U. (2008). Family-supportive organization perceptions, multiple dimensions of work-family conflict, and employee satisfaction: A test of model across five samples. Journal of Vocational Behavior, 73, 92-106.

Lyubomirsky, S., \& Lepper, H. (1999). A measure of subjective happiness: Preliminary reliability and construct validation. Social Indicators Research, 46, 137-155.

MacDermid, S. M. (2005). (Re)Considering conflict between work and family. In E. E. Kossek \& S. J. Lambert (Eds.), LEA's organization and management series. Work and life integration: Organizational, cultural, and individual perspectives (pp. 19-40). Mahwah, NJ: Lawrence Erlbaum Associates Publishers.

Marks, S. R. (1977). Multiple roles and role strain: Some notes on human energy, time and commitment. American Sociological Review, 42(6), 921-936.

Matthews, R. A., Kath, L. M., \& Barnes-Farrell, J. L. (2010). A short, valid, predictive measure of work-family conflict: item selection and scale validation. Journal of Occupational Health Psychology, 15(1), 75-90.

McDonald, R. P. (1999). Test theory: A unified treatment. Mahwah, NJ: Erlbaum.

Mesmer-Magnus, J. R., \& Viswesvaran, C. (2005). Convergence between measures of work-to-family and family-to-work conflict: A meta-analytic examination. Journal of Vocational Behavior, 67, 215-232.

Meydan, C. H., \& Şeşen, H. (2011). Yapısal Eşitlik Modellemesi AMOS Uygulamaları [Structural Equation Modeling AMOS Applications]. Ankara: Detay Yayıncilik.

Michel, J. S., Mitchelson, J. K., Kotrba, L. M., LeBreton, J. M., \& Baltes, B. B. (2009). A comparative test of work-family conflict models and critical examination of work-family linkages. Journal of Vocational Behavior, 74, $199-218$.

Mokomane, Z. (2013). Chapter 1. Introduction. In Z. Mokomane (Ed.), Work-Family interface in Sub-Saharan Africa: Challenges and responses, (pp. 3-16). New York, NY: Springer.

Netemeyer, R. G., Boles, J. S., \& McMurrian, R. (1996). Development and validation of work-family conflict and familywork conflict scales. Journal of Applied Psychology, 81(4), 400-410.

Netemeyer, R. G., Brashear-Alejandro, T., \& Boles, J. S. (2004). A cross-national model of job-related outcomes of work role and family role variables: A retail sales context. Journal of the Academy of Marketing Science, 32(1), 49-60.

Nohe, C., \& Sonntag, K. (2014). Work-family conflict, social support, and turnover intentions: A longitudinal study. Journal of Vocational Behavior, 85, 1-12.

Nunnally, J. C., \& Bernstein, I. H. (1994). Psychometric Theory. 3rd Edition. New York, NY: McGraw-Hili, Inc.

O’Driscoll, M. P., Brough, P., \& Kalliath, T. J. (2004). Work/family conflict, psychological well-being, satisfaction and social support: A longitudinal study in New Zealand. Equal Opportunities International, 23(1/2), 36-56.

Parasuraman, S., \& Greenhaus, J. H. (1997). Chapter 1. The changing world of work and family. In S. Parasuraman \& J. H. Greenhaus (Eds.), Integrating work and family: Challenges and choices for a changing world, (pp. 3-14). Westport, CT: Greenwood Publishing Group.

Poelmans, S., O’Driscoll, M., \& Beham, B. (2005). An overview of international research on the work-family interface. In S. A. Y. Poelmans (Ed.), Work and family: An international research perspective (pp. 3-46). Mahwah, NJ: Lawrence Erlbaum Associates.

R Core Team (2016). R: A language and environment for statistical computing. R Foundation for Statistical Computing, Vienna, Austria. URL https://www.R-project.org/.

Revelle, W. (2017). Psych: Procedures for Personality and Psychological Research, Northwestern University, Evanston, Illinois, USA, https://CRAN.R-project.org/package=psych Version = 1.7.8.

Rosseel, Y. (2012). Lavaan: An R package for structural equation modeling. Journal of Statistical Software, 48(2), 1-36. URL http://www.jstatsoft.org/v48/i02/.

Rudolph, C. W., Michel, J. S., Harari, M. B., \& Stout, T. J. (2014). Perceived social support and work-family conflict: A comparison of Hispanic immigrants and non-immigrants. Cross Cultural Management, 21(3), 306-325.

Rupert, P. A., Stevanovic, P., \& Hunley, H. A. (2009). Work-family conflict and burnout among practicing psychologists. Professional Psychology: Research and Practice, 40(1), 54-61.

Shockley, K. M., \& Singla, N. (2011). Reconsidering work-family interactions and satisfaction: A meta-analysis. Journal of Management, 37(3), 861-886.

Steiger, J. H., \& Lind, J. C. (1980). Statistically based tests for the number of common factors. Paper presented at the Annual Meeting of the Psychonomic Society, Iowa City, IA.

Stephens, G. K., \& Sommer, S. M. (1996). The measurement of work to family conflict. Educational and Psychological Measurement, 56, 475-486. 
Tetrick, L., \& C. Buffardi, L. (2006). Measurement issues in research on the work-home interface. In F. Jones, R. J. Burke, \& M. Westman (Eds.), Work-life balance: A psychological perspective, (pp. 90-114). New York, NY: Psychology Press.

Tucker, L. R., \& Lewis, C. (1973). A reliability coefficient for maximum likelihood factor analysis. Psychometrika, 38(1), 110 .

van Steenbergen, E. F., \& Ellemers, N. (2009). Is managing the work-family interface worthwhile? Benefits for employee health and performance. Journal of Organizational Behavior, 30, 617-642.

Wang, Y., \& Peng, J. (2017). Work-Family conflict and depression in Chinese professional women: The mediating roles of job satisfaction and life satisfaction. International Journal of Mental Health and Addiction, 15(2), 394-406. 